University of Nebraska - Lincoln

DigitalCommons@University of Nebraska - Lincoln

Faculty Publications in Food Science and Technology

Food Science and Technology Department

2010

\title{
Functionality of Native Tetraploid Wheat Starches: Effects of Waxy Loci Alleles and Amylose Concentration in Blends
}

\author{
L. E. Hansen \\ USDA-ARS
}

David S. Jackson

University of Nebraska-Lincoln, djackson1@unl.edu

R. L. Wehling

University of Nebraska-Lincoln, rwehling1@unl.edu

J. D. Wilson

USDA-ARS

Robert A. Graybosch

University of Nebraska-Lincoln, bob.graybosch@ars.usda.gov

Follow this and additional works at: https://digitalcommons.unl.edu/foodsciefacpub

Part of the Food Science Commons

Hansen, L. E.; Jackson, David S.; Wehling, R. L.; Wilson, J. D.; and Graybosch, Robert A., "Functionality of Native Tetraploid Wheat Starches: Effects of Waxy Loci Alleles and Amylose Concentration in Blends" (2010). Faculty Publications in Food Science and Technology. 107.

https://digitalcommons.unl.edu/foodsciefacpub/107

This Article is brought to you for free and open access by the Food Science and Technology Department at DigitalCommons@University of Nebraska - Lincoln. It has been accepted for inclusion in Faculty Publications in Food Science and Technology by an authorized administrator of DigitalCommons@University of Nebraska - Lincoln. 


\title{
Functionality of native tetraploid wheat starches: Effects of waxy loci alleles and amylose concentration in blends
}

\author{
L.E. Hansen ${ }^{\text {a }}$, D.S. Jackson ${ }^{\text {b }}$, R.L. Wehling ${ }^{\text {b }}$, J.D. Wilson ${ }^{c}$, R.A. Graybosch ${ }^{\text {a,* }}$ \\ a USDA-ARS, Lincoln, NE, USA \\ ${ }^{\mathrm{b}}$ Department of Food Science and Technology, University of Nebraska-Lincoln, USA \\ ${ }^{\mathrm{c}}$ USDA-ARS, Grain Marketing and Production Research Center, Manhattan, KS, USA
}

\section{A R T I C L E I N F O}

\section{Article history:}

Received 3 September 2009

Received in revised form

3 February 2010

Accepted 25 February 2010

\section{Keywords:}

Durum wheat

Starch

Functional properties

Amylose

Waxy alleles

\begin{abstract}
A B S T R A C T
Partial waxy (reduced amylose) and fully waxy (amylose-free) tetraploid durum wheats (Triticum turgidum L. var. durum) were used to investigate the relationships between both intra- and inter-granular variation in amylose concentration and starch functionality. Starches isolated from each genotype (intragranular amylose variants) were compared to those of commercially available hexaploid wild-type and waxy starches, and functionalities compared to blends (inter-granular variants) of durum waxy and wildtype starches of $0,6,12,18,24, \& 30 \%$ amylose content. Starch particle size distributions were not significantly different amongst partial waxy and wild-type genotypes; waxy samples had significantly smaller mean starch granule size. Few significant differences for crystallite melting and related intrinsic heat as determined by differential scanning calorimetry (DSC) were observed. The detected differences in starch gel color or gel strength generally were observed for the waxy samples relative to wild-type. Numerous significant differences were observed via Rapid-Visco Analysis (RVA). Pasting peak viscosity and breakdown were inversely proportional to \% amylose. $W x-B 1$ null final viscosity differed significantly from that of all other blends and genotypes, demonstrating that genotypic differences exist amongst the partial waxy types, independent of amylose concentration per se.
\end{abstract}

Published by Elsevier Ltd.

\section{Introduction}

Wild-type wheat starch granules typically contain 25-30\% amylose, an essentially straight chain polymer of $1,4-\alpha$-linked glucose, and $70-75 \%$ amylopectin, a polymer of $\alpha-1,6$-branched 1,4- $\alpha$-linked glucose chains (BeMiller and Whistler, 1996). Two forms of the granule-bound starch synthase (GBSS, E.C. 2.4.1.242), the enzyme which synthesizes amylose, are produced in durum (Triticum turgidum L. var. durum) and other tetraploid wheats, one each by the $W x-A 1$ and $W x-B 1$ loci (Yamamori et al., 1995). Fully waxy (amylose-free) and partial waxy (reduced amylose) genotypes have been produced in durum wheat (Delwiche et al., 2006; Sharma et al., 2002; Vignaux et al., 2004). Partial waxy types contain a non-functional (null) gene at one of the two $W x$ loci. The fully waxy condition results when both nulls are present.

\footnotetext{
* Corresponding author. USDA-ARS, 314 Biochemistry Hall, University of Nebraska-Lincoln, East Campus, Lincoln, NE 68583, USA. Tel.: +1 402472 1563; fax: +14024724020.

E-mail address: bob.graybosch@ars.usda.gov (R.A. Graybosch).
}

The functional characters of waxy hexaploid wheat (T. aestivum L.) starches have been extensively investigated (Epstein et al., 2002; Kim et al., 2003; Yamamori and Quynh, 2000). Comparatively little is known of the effects of amylose variation in durum wheat starch. Gianibelli et al. (2005) found that the addition of waxy starch from bread wheats to semolina, decreased firmness and increased stickiness in pasta. They suggested "No improvement in pasta quality should be expected if the waxy character is introduced in durum wheat." Urbano et al. (2002), using both protein- and DNAbased assays, detected one null allele at the $W x$-A1 locus and three different null alleles at the $W x-B 1$ locus of $T$. turgidum var. durum, but they reported no effects on amylose content or functionality. Partial waxy durum wheats have been generated by other investigators (Vignaux et al., 2004, 2005). Grant et al. (2001) compared starch from two waxy durum lines to starches from four wild-type cultivars, and found higher swelling power but greater solubility in the waxy starches at $95^{\circ} \mathrm{C}$. Starch pasting was earlier, and peak viscosities were higher, for starches from both waxy lines than for the nonwaxy starches, but they broke down faster under continued stirring and heating. Melting temperatures, as measured by differential scanning calorimetry (DSC) were higher in the waxy starches. Grant et al. (2004), in a subsequent investigation, found 
acceptable spaghetti quality only with blends of $20-40 \%$ waxy semolina. Higher concentrations of waxy semolina reduced quality to unacceptable levels. Sharma et al. (2002), found that durum lines with the $w x-B 1$ null allele had significantly lower amylose content, higher starch pasting peak viscosity, and higher semolina swelling power than comparable wild-type lines. Chakraborty et al. (2004) investigated waxy durum starch properties, but compared them only to a parental wild-type line, and did not include investigations of partial waxy types.

The most comprehensive investigations of waxy durum starch to date have been those of Vignaux et al. (2004, 2005). Using nearisogenic lines produced after back-crossing to the durum cultivar 'Ben', Vignaux et al. (2004) found no amylose in waxy lines but observed no reduction in amylose content in partial waxy lines. Vignaux et al. (2005), using DSC, found waxy starch melting temperatures to be higher than partial waxy and wild-type starches, with both higher onset and final temperatures of the melting profile. Vignaux et al. (2005) also found cooked waxy pasta to be softer with higher cooking loss than pasta made from wildtype durum cultivars. Partial waxy pasta properties were similar to results obtained from wild-type pasta, which perhaps was as expected when amylose reduction was not observed in these genotypes. Vignaux et al. (2005) concluded waxy durum would not offer benefits to pasta producers.

Aside from the investigations of Vignaux et al. (2004, 2005) most previous studies have compared waxy and/or partial waxy durum lines to wild-type lines of diverse genetic background. The present study was undertaken to investigate waxy and partial waxy durum starch properties in experimental materials in which confounding effects of diverse genetic backgrounds have been eliminated. This was accomplished by utilizing sister lines of the four possible waxy genotypes produced in four genetic backgrounds. This approach also eliminates the possibility of results being confounded by use of only a single genetic background. Secondary goals were to compare the effects of amylose variation within starch granules to that induced by blending of waxy and wild-type wheats (inter-granular variation), and to investigate the effects of waxy and partial waxy durum starches on starch granule size distribution and gel color and texture, characteristics not previously investigated.

\section{Experimental}

\subsection{Wheat samples}

Sets of wild-type, partial waxy ( $W x-A 1$ null or $W x-B 1$ null), and waxy ( $W x-A 1$ and $W x-B 1$ double-null) durum wheat lines were developed in 4 genetic backgrounds, designated "populations" (Delwiche et al., 2006). Three lines each of the four possible tetraploid wheat GBSS genotypes were identified per population. The lines were planted at Yuma, AZ, in 2003 and 2004 in a randomized complete block design with three replications. Two of the three field replications were used for subsequent analyses. GBSS genotypes of field-grown samples were confirmed by testing bulk samples of 8-12 seeds per line by SDS-PAGE and silver staining (Kim et al., 2003). In addition, wild-type, $W x$ - $A 1$ null, and $W x-B 1$ null lines were further analyzed by evaluation of $6-8$ single seeds (as independent samples). Samples from harvest years 2003 or 2004 samples were composited as equal weights of grain across populations by GBSS genotype, retaining crop year identities.

\subsection{Milling and starch isolation}

Moistures for grain, mill product, and starch were determined using the aluminum plate and air-oven method (Methods 44-16 and 44-15A, AACC, 2000). Tempering adjustment to $14 \%$ moisture was required to improve milling. Tempered samples were milled (AACC Method 26-50) on a Brabender (Duisburg, Germany) Quadrumat Junior Laboratory Mill. The material passing through a U.S. No. 40 sieve with shaking for $4 \mathrm{~min}$ was weighed for flour milling yield and retained as the mill product.

Starch was repeatedly isolated from $200 \mathrm{~g}$ subsamples of drymilled flour by dough ball washing (AACC Method 38-10). The slurry was passed through U.S. No. $161.18 \mathrm{~mm}$ and U.S. No. 230 $63 \mu \mathrm{m}$, sieves and allowed to aggregate and precipitate for $12 \mathrm{~h}$. The resulting liquid phase was removed by aspiration, and starch purified over a flow table (Wehling et al., 1993). The residual nitrogen in the starch was estimated (AACC Method 46-30) and converted to \% protein using a factor of 5.7. After isolation, all starches were passed through a $1 \mathrm{~mm}$ screen on an Udy Cyclone Mill (UDY Corporation, Ft. Collins, CO). The protein and fat contents of the starches were analytically determined by an independent commercial laboratory (Ward Laboratories, Hastings, NE).

\subsection{Particle size distribution}

Starch particle size distributions of each genotype and two commercially prepared hexaploid wheat starch samples (one waxy and one wild-type) were determined using a single wavelength Beckman Coulter LS 13320 Particle Size Analyzer (Beckman Coulter, Miami, FL) with the Universal Liquid Module for liquidbased measurements (Park et al., 2009). Commercial starch samples were obtained from MGP Ingredients (Atchison, KS) and Archer Daniels-Midland (Decatur, IL). Volumes of all starch granules were calculated on the assumption that all granules were spherical in shape and reported as differential volume percent, the population of particles at each diameter. The curve descriptors (mean, median, standard deviation, mode, skewness, and kurtosis) were included.

\subsection{Amylose content determinations and blending}

Percent amylose concentration of the isolated starches was determined by the dual wavelength amylose assay (Zhu et al., 2007). The waxy and wild-type starches were blended by weight using moistures and amylose values to approximately $30 \%$ amylose or fully wild-type, $24 \%, 18 \%, 12 \%, 6 \%$ amylose and $0 \%$ amylose or fully waxy starch. Separate blends were produced for each harvest year. After mechanical mixing with counter-top bowl mixers using a paddle on low speed for $15 \mathrm{~min}$, the percent amylose content of all blends was empirically determined by the dual wavelength assay.

\subsection{Paste viscosity and opacity}

Rapid-Visco Analysis (RVA) utilized the Series 4 Rapid ViscoAnalyser (Newport Scientific Pty. Ltd, Warriewood, NSW, Australia) Standard Protocol 1. The starch paste after RVA was transferred to an aluminum weigh pan $5 \mathrm{~cm}$ diameter $\times 1.5 \mathrm{~cm}$ deep. The weigh pan was placed into a closeable aluminum cake pan and held for $72 \mathrm{~h}$ at $+4{ }^{\circ} \mathrm{C}$. After 3 days the gels were allowed to equilibrate to room temperature for $30 \mathrm{~min}$. Starch gel opacity was determined as the color shift of reflected light from the surface of the aluminum pan through the starch gel. A Minolta Chromameter CR300 with DP301 data processor (Minolta Corp., 101 Williams Drive, Ramsey, NJ 07446) was calibrated to a standard white porcelain plate (CRA48 Plate Set, Minolta Corp.) whose color parameters (x, y, and Y) were known. A polystyrene Petri dish was inverted over an empty weighing pan and the Hunter $\mathrm{L}, \mathrm{a}$, and $\mathrm{b}$ values determined in triplicate. The direct reflected measurements were: $\mathrm{L}=$ brightness, 
Table 1

Particle size distributions and amylose content of native starches isolated from durum wheats grown at Yuma, AZ in 2003 and 2004.

\begin{tabular}{llllllll}
\hline Treatment & $\begin{array}{l}\text { Mean } \\
(\mu \mathrm{m})\end{array}$ & $\begin{array}{l}\text { Median } \\
(\mu \mathrm{m})\end{array}$ & $\begin{array}{l}\text { Mode } \\
(\mu \mathrm{m})\end{array}$ & $\begin{array}{l}\text { STD } \\
(\mu \mathrm{m})\end{array}$ & Skewness & Kurtosis & $\begin{array}{l}\text { Amylose } \\
\text { content }(\%)\end{array}$ \\
\hline AN & 14.83 & 14.85 & 21.69 & 8.92 & 0.21 & -0.88 & 27.90 \\
BN & 14.62 & 14.39 & 20.73 & 9.09 & 0.35 & -0.65 & 24.25 \\
WT & 15.61 & 15.75 & 21.69 & 9.27 & 0.20 & -0.88 & 29.85 \\
WX & 12.03 & 11.70 & 18.88 & 7.70 & 0.29 & -0.93 & 0.00 \\
Mean & 14.27 & 14.17 & 20.75 & 8.74 & 0.26 & -0.83 & 20.50 \\
l.s.d. $(0.05)$ & 0.81 & 2.03 & n.s. & 0.94 & n.s. & n.s. & 2.57 \\
\hline
\end{tabular}

$\mathrm{AN}=W x-A 1$ null, $\mathrm{BN}=W x-B 1$ null, $\mathrm{WX}=$ waxy, $\mathrm{WT}=$ wild-type.

which ranged from $0=$ black to $100=$ white; $a=$ red/green color, which ranged from negative $=$ green to positive $=$ red; and $\mathrm{b}=$ blue/yellow color, which ranged from negative $=$ blue to positive $=$ yellow. The color shift from the empty aluminum pan caused by the starch gels was $\mathrm{dE}=$ total color shift which accounted for the shift in all three axes ( $\mathrm{dL}$, da, and $\mathrm{db}$ ), $\mathrm{dL}=$ shift in brightness (most closely related to gel opacity) from the empty aluminum weighing pan, $\mathrm{da}=$ shift in red/green from the empty aluminum weighing pan color, and $\mathrm{db}=$ shift in blue/yellow from the empty aluminum weighing pan color.

The Hue Angle, or the angle in radians of the Hunter a and Hunter $b$ color co-ordinates plotted on a plane perpendicular to
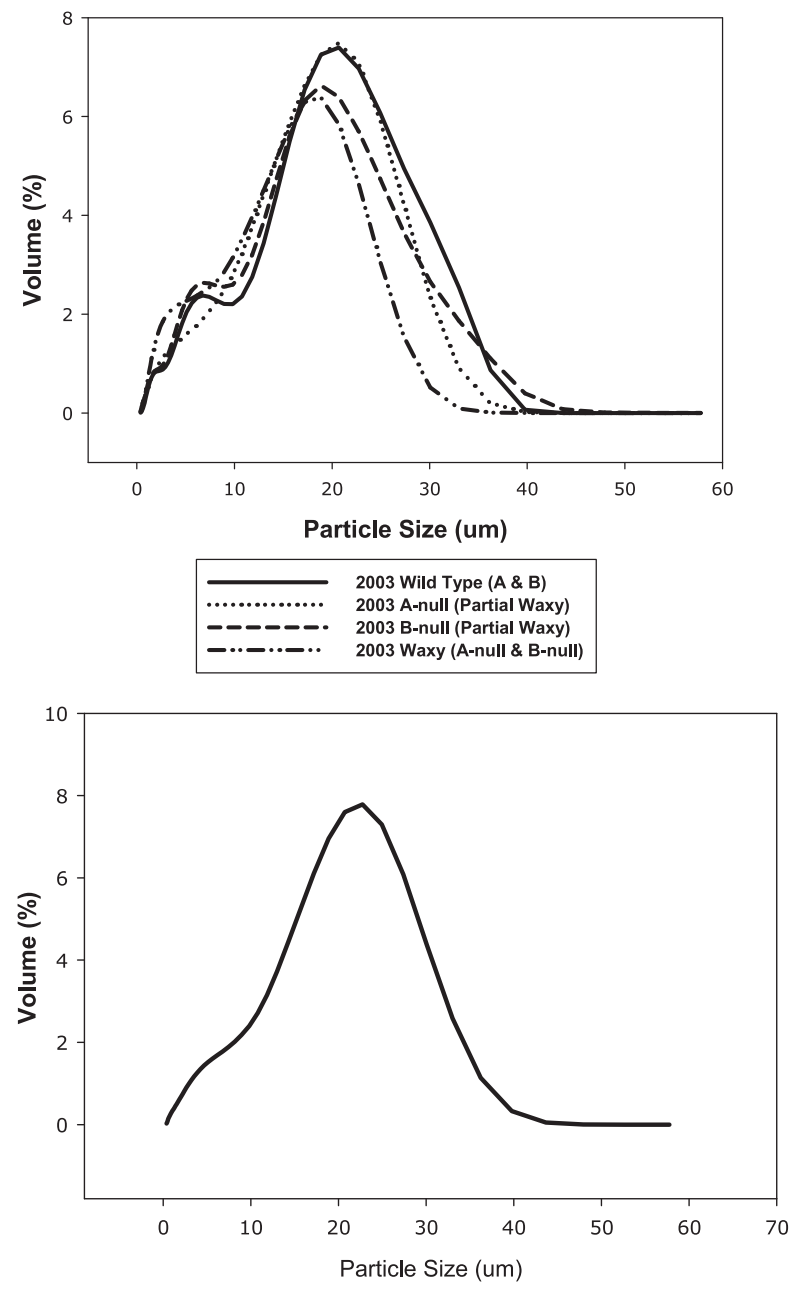

Commercial wild-type hexaploid wheat the brightness axis, was also determined. The angle of the hue, color, was the inverse of the tangent determined by the ratio of Hunter b to Hunter a. For statistical comparison, the angles were transformed to first quadrant representations which produced some angles greater than $2 \times \pi$. Mclellan et al. (2007) determined Hue $=$ Arc $\tan (\mathrm{b} / \mathrm{a})$ could be used directly if both $\mathrm{a}$ and $\mathrm{b}$ were positive. When $[-\mathrm{a},+\mathrm{b}]$ and $[-\mathrm{a},-\mathrm{b}]$ were encountered, the function became Hue $=\pi+\operatorname{Arc} \tan (b / a)$, where $\pi$ was in radians. When $[+a,-b]$ was encountered, the function became Hue $=(2 \times \pi)+\operatorname{Arctan}(b / a)$, where $\pi$ was in radians. The Hunter $\mathrm{a}$ and Hunter $\mathrm{b}$ shifts were also given a radian representation using the same quadrant transformations as above substituting $\mathrm{da}$ for $\mathrm{a}$ and $\mathrm{db}$ for $\mathrm{b}$.

\subsection{Texture analysis}

Starch gel textural response after $72 \mathrm{~h}$ was observed with a TA. $X T 2 i$ Texture Analyzer (Texture Technologies Corp., Scarsdale, NY, USA) equipped with a $25 \mathrm{~N}$ load cell and $2.54 \mathrm{~cm}$ diameter acrylic probe and utilized Texture Expert ${ }^{\mathrm{TM}}$ texture analysis software for instrumental control, output and calculations. Integration of the area (Area1) underneath the compression stroke indicated gel strength. The probe withdrawal portion of the curve (Area2) indicated adhesion.
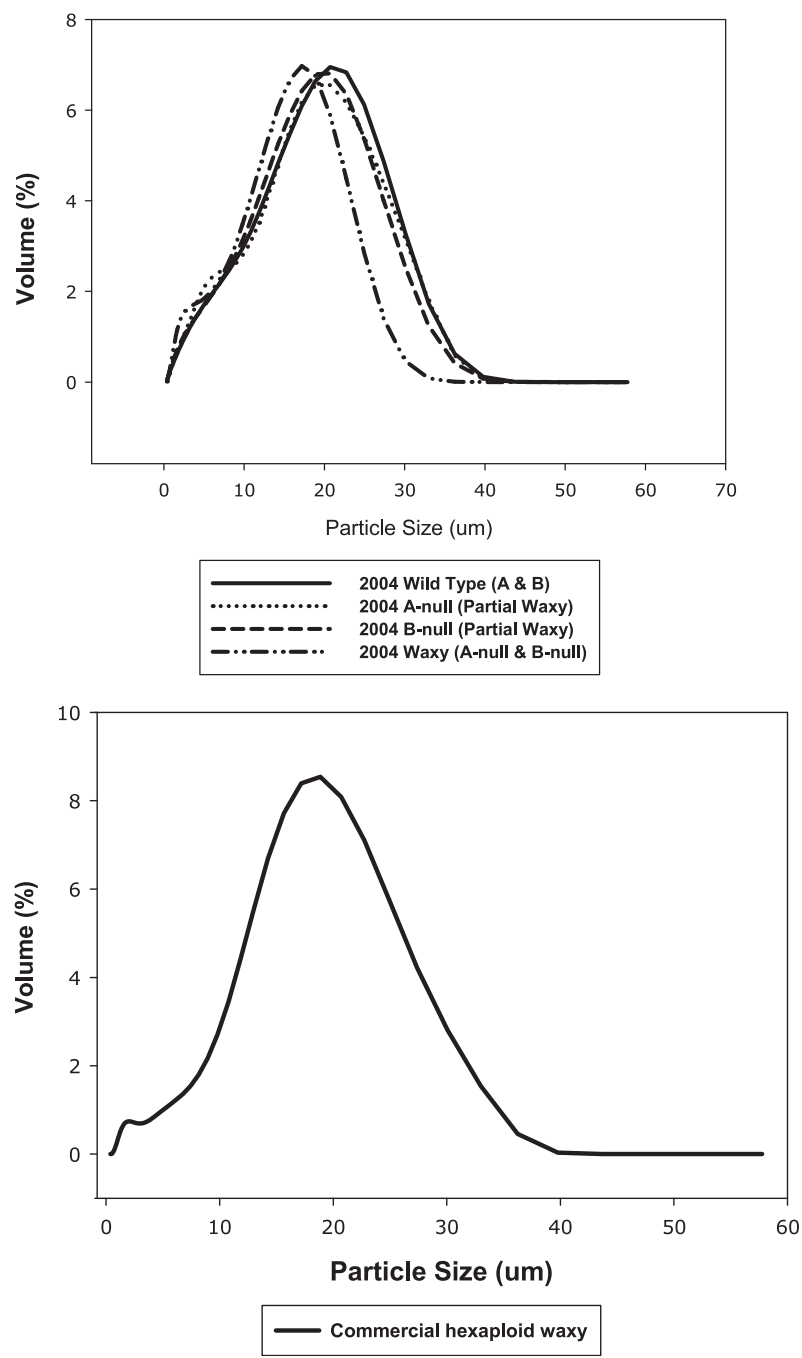

Fig. 1. Particle size distributions of starches purified from tetraploid durum wheats, starch blends, and commercially prepared hexaploid wheat starches. 


\subsection{Thermal transition}

Differential Scanning Calorimetry (DSC) (Pyris 7 Diamond DSC, Perkin-Elmer Life \& Analytical Sciences, Inc., Wellesley, MA, USA) analyses were patterned after Ratnayake and Jackson (2006) and Pedersen et al. (2007). Approximately 10-14 mg starch was transferred to a high-pressure stainless steel pan (PN: 03190029, PerkinElmer, Norwalk, CT), the actual weight recorded, $55 \mu \mathrm{l}$ autoclaved distilled de-ionized water was added and the pan sealed with an o-ring and cover. The sealed pans were held over night at room temperature allowing the starch granules time to fully hydrate. The sample weight was corrected to a dry weight basis. Samples were allowed to equilibrate to $25^{\circ} \mathrm{C}$ for $2 \mathrm{~min}$ before heating to $120^{\circ} \mathrm{C}$ at $10^{\circ} \mathrm{C} / \mathrm{min}$. The DSC, calibrated to indium, compared the heat transferred to the sample versus an empty highpressure stainless steel pan as reference. Pyris software was used to capture thermograms and calculate the physical transition temperatures (onset, peak height, and end) and heat of physical transition (area of the peak=heat of transition, and enthalpy $=$ heat of transition per unit mass).

\subsection{Statistical analysis}

All assays were conducted in triplicate. Statistical analyses were performed using PC-SAS 9.1 (SAS Institute, Cary, NC). Analysis of variance was used to evaluate variation due to the main effects crop year, type (defined as genotypes, or inter-granular blends of waxy with wild-type) and year by type interactions for each physical property. Mean responses of types were calculated over crop years and were compared by computation of least significant differences $(\mathrm{p}=0.05)$ using appropriate error terms.

\section{Results and discussion}

\subsection{Starch physical and chemical properties}

Chemical composition of experimentally isolated durum starches was similar to that of the commercial hexaploid starch preparations. Mean protein concentration of isolated durum starches ranged from 0.1 to $0.4 \%$; mean protein concentration of commercially prepared wild-type and waxy hexaploid starches was 0.2 and $0.3 \%$, respectively. Mean fat concentration of the durum starches ranged from 0.0 to $0.3 \%$; both commercially prepared hexaploid starches had identical fat contents of $0.3 \%$.

Isolated waxy durum starches displayed a significantly smaller mean granule size when compared to all other genotypes (Table 1). The partial waxy genotypes did not differ from each other, nor did they differ from the wild-type. There were no differences in skewness or kurtosis of the particle size curves. The genotypic distribution curves were visually similarly except there was a shift in the waxy sample to slightly smaller granules than in the other types. No significant difference of the particle size distribution due to crop year was found (not shown).

The isolated waxy and wild-type starches also were compared to commercially prepared hexaploid wheat wild-type and waxy starches for distribution curve shape (Fig. 1). Mean granule size (16.8 and $16.3 \mu \mathrm{m}$ for wild-type and waxy, respectively) of both commercial preparations was slightly larger than that of all durum samples. Otherwise, the shape of the size distribution curves of the durum starch samples was similar to the commercial preparations.

Functionality of wheat starch has been reported to be a consequence of the reactivity difference between A-type granules, larger than $10 \mu \mathrm{m}$ and lenticular shaped, and B-type granules, smaller than $10 \mu \mathrm{m}$ and more spherically shaped (Bertolini et al., 2003; Geera et al., 2006), as well as the \% amylose content (Graybosch,
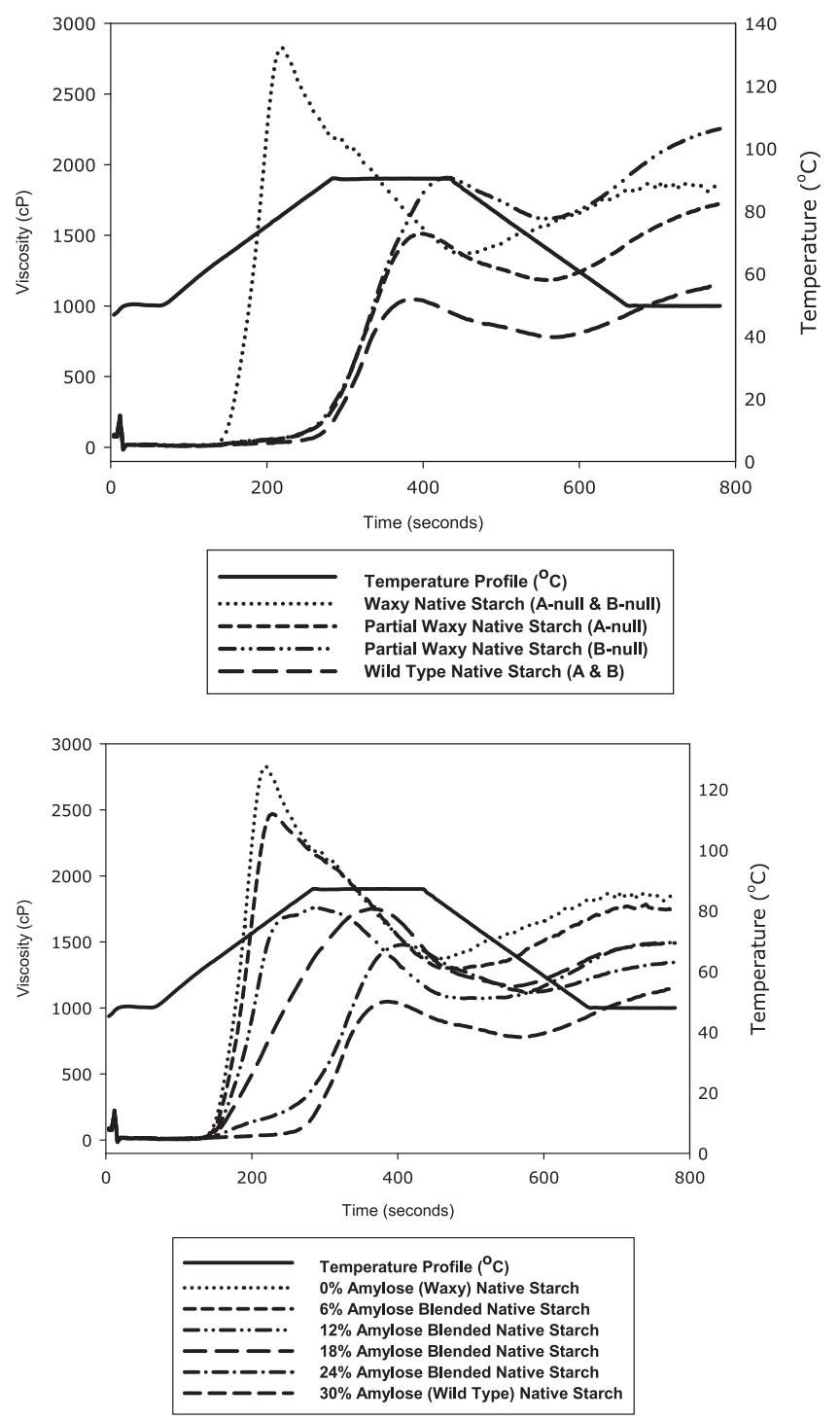

Fig. 2. Starch pasting properties of tetraploid durum wheat starches and starch blends.

1998). A contribution of smaller starch granule size to differences in functional properties of waxy durum starches (below) cannot be discounted.

There was a significant difference for mean amylose content of the genotypes, (Table 1). The dual wavelength method recorded no measurable amylose content in the waxy starch preparations. Mean amylose concentration of the $W x-B 1$ null samples was significantly lower than that of the $W x-A 1$ and wild-type samples. The latter two samples did not differ significantly from each other. Similar differential effects of $W x$ null alleles have been observed in hexaploid wheats (Yamamori and Quynh, 2000). Vignaux et al. (2004) found no reduction in amylose content of partial waxy durum types. The discrepancy between the two studies could merely arise from the use of different genetic backgrounds, or different cultural environments.

\subsection{Starch paste viscosity}

Waxy samples had the highest RVA peak viscosity, and the shortest time to peak (Fig. 2, Table 2). Partial waxy and wild-type genotypes had identical times to peak viscosity, but differed in peak 
Table 2

Means from Rapid-Visco Analysis of native \&\% amylose blended starches purified from tetraploid wheat grown in 2003 \& 2004.

\begin{tabular}{lrrrrlll}
\hline Treatment & ViscP & ViscTr & Brakdn & ViscF & Setbak & PkTime & Tpaste \\
\hline 6 & 2497 & 1292 & 1205 & 1736 & 444 & 3.82 & 51.59 \\
12 & 2014 & 1211 & 804 & 1703 & 493 & 4.73 & 50.88 \\
18 & 1754 & 1162 & 592 & 1492 & 330 & 6.08 & 52.52 \\
24 & 1480 & 1116 & 364 & 1344 & 228 & 6.79 & 51.11 \\
AN & 1513 & 1180 & 333 & 1723 & 543 & 6.61 & 51.79 \\
BN & 1896 & 1421 & 475 & 2254 & 833 & 7.00 & 53.35 \\
WT & 1050 & 776 & 274 & 1152 & 376 & 6.42 & 54.35 \\
WX & 2867 & 1354 & 1513 & 1821 & 468 & 3.64 & 50.97 \\
Mean & 1884 & 1189 & 695 & 1653 & 465 & 5.64 & 52.07 \\
l.s.d. & 214 & 220 & 133 & 276 & 133 & 0.27 & 2.59 \\
\hline
\end{tabular}

$\mathrm{WX}=$ waxy genotype or $0 \%$ amylose, $\mathrm{WT}=$ wild-type genotype or $30 \%$ amylose, $\mathrm{AN}=W x-A 1$ null partial waxy genotype, $\mathrm{BN}=W x-B 1$ null partial waxy genotype, $6=6 \%$ amylose, $12=12 \%$ amylose, $18=18 \%$ amylose, $24=24 \%$ amylose; $\mathrm{Visc} \mathrm{P}=$ the peak viscosity; $\mathrm{ViscTr}=$ the trough or hot paste viscosity; Brakdn $=$ the breakdown, shear thinning, or difference between the peak viscosity and the hot paste viscosity; $\mathrm{ViscF}$ = the final or cold paste viscosity; Setbak = the set back, or the difference between the hot paste viscosity and the cold paste viscosity; PkTime $=$ the time from the start of the run to the peak viscosity; TPaste $=$ the pasting temperature which was associated with the onset of gelatinization.

viscosity levels. The $W x-B 1$ null presented higher peak viscosity than $W x-A 1$ null and wild-type, and also demonstrated the highest final viscosity, exceeding even the waxy samples. Similar results were obtained by Vignaux et al. (2005) although in their study no differences in peak viscosities of waxy and $W x-B 1$ null types were detected. With blended samples, peak and final viscosities were directly proportional to amylose content (Fig. 2, Table 2). Samples with 0,6 and $12 \%$ amylose content showed the earliest peak viscosities, all less than $5 \mathrm{~min}$. At amylose contents above $12 \%$, a shift in peak viscosity occurred, with times in the range of 6-7 min, similar to times observed for partial waxy and wild-type genotypes.

The observed peak viscosities for the inter-granule blended starches and their relation to \% amylose content has been reported for hexaploid wheats (Yamamori and Quynh, 2000). Araki et al. (2000), indicated, however, some variation independent of amylose content may be produced by nulls at the $W x$ loci. Properties of the $W x-B 1$ null durum samples confirmed this observation. Peak and final viscosities of the $W x-B 1$ null samples (amylose content $=24.25 \%$ ) were significantly different from those of the $24 \%$ blend formed via the combination of waxy and wild-type samples. Partial waxy $W x-B 1$ null starch also was not significantly different from either the $12 \%$ amylose starch or $18 \%$ amylose starch blends. $W x-A 1$ null (intra-granular $26 \%$ amylose) starch was not significantly different from the $24 \%$ amylose inter-granular blend. Thus, amylose variation within a starch granule can impart properties that differ from those observed when amylose variation arises from the blending of amylose-free (waxy) and amylose-bearing (wildtype) samples.

\subsection{Starch gel opacity and texture}

Gel opacity has been reported to correlate with \% amylose dispersed in the starch gel (Guo et al., 2002). The Hunter L and dL values of the blended starches of less than $24 \%$ amylose were uniformly lower than the values of non-blended starch samples (Table 3). Comparisons of reflected light indicated a significant difference for brightness (Hunter L) with the 6\% amylose blend gel among the least bright, and waxy and wild-type gels among the brightest. On the Hunter a axis, the waxy starch gel was the most positive a-value and was significantly different from all other gels. Wild-type gel was among the most negative a-values. On the Hunter b axis the waxy starch gel was the only positive b-value and significantly different from the other gels, with the wild-type gel again amongst the most negative b-values. The $6 \%, 12 \% \& 18 \%$ intergranule blend b-values were significantly different from each other and inversely proportional to amylose content (Table 3).

Total color shift, Hunter $\mathrm{dE}$, showed 6\% amylose having the greatest effect on reflected light, and waxy and wild-type gel having the least effect (Table 3 ). Trends in the brightness shift, Hunter dL, were reversed from dE. The red-green shift, Hunter da, indicated waxy as having the only positive a-shift and wild-type with the greatest negative a-shift values. Regarding the yellow-blue shift, Hunter $\mathrm{db}$, only the waxy gel had a positive and significantly different b-shift, while the wild-type gel was among the significantly different most negative b-shift values. The blue shift, negative Hunter $b$, indicated a trend of increased blue with increased inter-granular amylose content (Table 3 ).

Hue angle results again indicated unique properties for waxy starch. The waxy gel had the smallest and only significantly different hue angle. All of the other gels were not significantly different from each other. Hue angle shift of the waxy gel was significantly different from the other gels and had the lowest angle. Gels from all of the other genotypes and \% amylose blends were not significantly different from each other, (Table 3). Use of waxy starch in food products likely will be accompanied by changes in product clarity and appearance.

Texture analysis found wild-type gels to be among the firmest (Area1) and significantly different from waxy gels (Table 3). Waxy gels were among the most negative or viscid gels for Area2 and significantly different from wild-type gels which were among the

Table 3

Means of gel color and texture analysis of starches purified from tetraploid wheat grown in 2003 \& 2004 .

\begin{tabular}{|c|c|c|c|c|c|c|c|c|c|c|c|}
\hline \multirow[t]{2}{*}{ Treatment } & \multicolumn{9}{|c|}{ Minolta chromameter analysis } & \multicolumn{2}{|l|}{ Texture analysis } \\
\hline & $\mathrm{L}$ & $\mathrm{a}$ & $\mathrm{b}$ & $\mathrm{dE}$ & $\mathrm{dL}$ & da & $\mathrm{db}$ & Hue & dHue & $\begin{array}{l}\text { Area1 (Newton } \\
\text { seconds) }\end{array}$ & $\begin{array}{l}\text { Area2 (Newton } \\
\text { seconds) }\end{array}$ \\
\hline 6 & 35.18 & 0.06 & -0.54 & 37.55 & -37.54 & -0.13 & -1.08 & 4.90 & 4.58 & 1.626 & -0.308 \\
\hline 12 & 36.33 & -0.15 & -2.44 & 36.80 & -36.68 & -0.29 & -2.92 & 4.65 & 4.61 & 2.508 & -0.447 \\
\hline 18 & 38.49 & -0.29 & -4.06 & 34.91 & -34.62 & -0.42 & -4.53 & 4.64 & 4.62 & 4.942 & -0.170 \\
\hline 24 & 40.49 & -0.44 & -5.01 & 33.10 & -32.64 & -0.49 & -5.53 & 4.63 & 4.63 & 11.262 & 0.524 \\
\hline AN & 43.26 & -0.59 & -5.92 & 31.03 & -27.97 & -1.09 & -6.42 & 4.61 & 4.55 & 17.620 & 2.201 \\
\hline BN & 41.16 & -0.50 & -5.15 & 31.79 & -31.28 & -0.92 & -5.57 & 4.61 & 4.55 & 8.542 & 1.555 \\
\hline WT & 44.05 & -0.71 & -6.02 & 29.45 & -28.71 & -0.98 & -6.53 & 4.60 & 4.56 & 23.782 & 3.009 \\
\hline Wx & 45.91 & 0.48 & 3.86 & 27.07 & -26.82 & 0.19 & 3.37 & 1.44 & 1.51 & 1.606 & -0.265 \\
\hline Mean & 40.61 & -0.26 & -3.12 & 32.71 & -32.03 & -0.52 & -3.65 & 4.27 & 4.21 & 8.986 & 0.762 \\
\hline l.s.d. & 6.01 & 0.25 & 1.00 & 5.65 & 6.89 & 0.56 & 0.94 & 0.19 & 0.11 & 7.620 & 1.155 \\
\hline
\end{tabular}

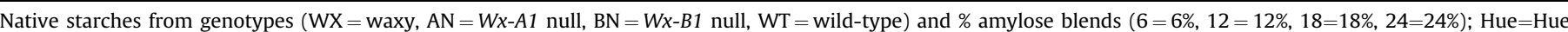

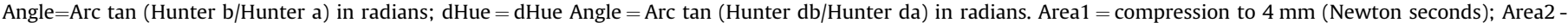

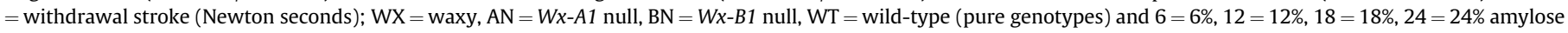
(blended) starches. 
Table 4

Differential scanning calorimetry evaluation of native starches purified from durum wheat grown in 2003 \& 2004.

\begin{tabular}{|c|c|c|c|c|c|c|c|}
\hline Treatment & $\begin{array}{l}\text { Initial } \\
\left({ }^{\circ} \mathrm{C}\right)\end{array}$ & $\begin{array}{l}\text { Onset } \\
\left({ }^{\circ} \mathrm{C}\right)\end{array}$ & $\begin{array}{l}\text { Peak } \\
\left({ }^{\circ} \mathrm{C}\right)\end{array}$ & $\begin{array}{l}\text { End } \\
\left({ }^{\circ} \mathrm{C}\right)\end{array}$ & $\begin{array}{l}\text { Final } \\
\left({ }^{\circ} \mathrm{C}\right)\end{array}$ & $\begin{array}{l}\text { Area } \\
(\mathrm{mJ})\end{array}$ & $\begin{array}{l}\Delta \mathrm{H} \\
(\mathrm{mJ} / \mathrm{g})\end{array}$ \\
\hline 6 & 49.11 & 53.24 & 62.04 & 71.33 & 77.56 & 152.32 & 15.66 \\
\hline 12 & 47.84 & 51.40 & 60.11 & 67.68 & 73.00 & 156.43 & 15.42 \\
\hline 18 & 49.52 & 52.96 & 61.07 & 69.41 & 74.62 & 161.66 & 15.40 \\
\hline 24 & 48.18 & 52.87 & 60.52 & 68.94 & 74.59 & 174.35 & 15.24 \\
\hline AN & 48.59 & 53.11 & 60.99 & 68.72 & 75.63 & 171.77 & 14.91 \\
\hline $\mathrm{BN}$ & 49.28 & 53.50 & 60.18 & 66.09 & 70.42 & 135.30 & 14.54 \\
\hline WT & 47.73 & 52.32 & 59.94 & 68.53 & 73.99 & 172.41 & 14.52 \\
\hline WX & 48.60 & 53.66 & 62.24 & 72.17 & 77.26 & 174.22 & 12.49 \\
\hline Mean & 48.61 & 52.88 & 60.89 & 69.11 & 74.63 & 162.31 & 14.77 \\
\hline $\mathrm{Cv}(\%)$ & 3.48 & 1.98 & 2.45 & 3.55 & 4.12 & 18.83 & 18.13 \\
\hline l.s.d. & n.s & n.s & 1.75 & 2.88 & 3.62 & 35.94 & 3.15 \\
\hline
\end{tabular}

Pure genotype $(\mathrm{WX}=$ waxy, $\mathrm{WT}=$ wild-type, $\mathrm{AN}=W x-A 1$ null, $\mathrm{BN}=W x-B 1$ null $)$ and blended $(6=6 \%, 12=12 \%, 18=18 \%, 24=24 \%)$ starches; Initial = peak beginning temperature; Onset=beginning of transition peak temperature; Peak $=$ transition peak temperature; End = ending transition peak temperature; Final = peak ending temperature; Area = heat of transition; $\Delta \mathrm{H}=$ enthalpy of transition; n.s = not significant.

most positive or clean releasing. Blended samples ranged between these extremes for both parameters and displayed results proportional to amylose content.

\subsection{Thermal transition}

No significant differences for the initial temperature and the onset temperature amongst samples were observed via DSC (Table 4). Only slight differences were observed in heat of transition and $\Delta$ H. Peak temperatures did reveal differences amongst the samples, with waxy having the highest value, wild-type the lowest, and blends assorted in proportion to amylose content. Similar results were observed with waxy and wild-type durum starches by Vignaux et al. (2005) but they observed no differences between partial waxy and wild-type starches. However, in their samples/ environment they also observed no differences in amylose content of partial waxy types, while the present investigation did. No doubt, amylose content, while strongly under the control of the waxy loci, still exhibits modification due to genetic background and environment. The $W x-B 1$ partial waxy type $(24.25 \%$ mean amylose content) again deviated from the trend, displaying a peak temperature similar to that of the $12 \%$ amylose content starch blend. Starch crystallite melting generally is not dependent on amorphous amylose, but more a function of amylopectin structure (Schenz, 2003; Stone and Morell, 2009). The observed DSC results most likely reflect the dilution of amylopectin by amylose. However, the unique response of the $W x$-B1 nulls might indicate some alteration of amylopectin structure within starch granules of this genotype.

Utilization of tetraploid durum wheat to produce partial waxy wheat starches simplified genetic characterization by reducing the number of genes involved, relative to hexaploid wheat. In hexaploid wheats, studies have indicated the starch amylose content produced in lines carrying either the $W X-D 1$ null or the $W x-A 1$ null alleles were equivalent while the starch amylose content was less in lines with the $W x-B 1$ null allele (Miura and Sugawara, 1996; Miura et al., 1999; Nakamura et al., 1993). In this study, the $W x$ B1 null starch (24\% amylose) was significantly reduced in amylose content being $2 \%$ less than the $W x-A 1$ null and $6 \%$ less than wildtype. In addition, $W x-B 1$ null starch displayed functional properties, particularly in starch pasting properties, not predicted by amylose content alone.

The largest change in functionality was observed with waxy starch. The properties of blended starches generally fell between the waxy and wild-type extremes, and generally were proportional to amylose content. End users can simply blend waxy and wildtype durum or likely also hexaploid wheat starches to achieve desired functionalities. In addition, $W x-B 1$ null durum wheat possesses unique attributes not predicted by amylose content alone.

\section{References}

AACC International, 2000. Approved Methods of the American Association of Cereal Chemists, 10th ed. The Association, St. Paul, MN, USA.

Araki, E., Miura, H., Sawada, S., 2000. Differential effects of the null alleles at the three $W x$ loci on the starch-pasting properties of wheat. Theoretical and Applied Genetics 100, 1113-1120.

BeMiller, J.N., Whistler, R.L., 1996. Carbohydrates. In: Fennema, Owen R. (Ed.), Food Chemistry, third ed. Marcel Dekker, Inc., New York, New York, pp. 157-204.

Bertolini, A., Souza, E., Nelson, J., Huber, K., 2003. Composition and reactivity of Aand B-type starch granules of normal, partial waxy, and waxy wheat. Cereal Chemistry 80, 544-549.

Chakraborty, M., Matkovic, K., Grier, D., Jarabek, E., Berzonsky, W., McMullen, M., Doehlert, D., 2004. Physicochemical and functional properties of tetraploid and hexaploid waxy wheat starch. Starch 56, 339-347.

Delwiche, S.R., Graybosch, R.A., Hansen, L.E., Souza, E., Dowell, F.E., 2006. Single kernel near-infrared analysis of tetraploid (durum) wheat for classification of the waxy condition. Cereal Chemistry 83, 287-292.

Epstein, J., Morris, C.F., Huber, K.C., 2002. Instrumental texture of white salted noodles prepared from recombinant inbred lines of wheat differing in the three granule bound starch synthase (waxy) genes. Journal of Cereal Science 35, 51-63.

Geera, B., Nelson, J., Souza, E., Huber, K., 2006. Composition and properties of A- and B-type starch granules of wild-type, partial waxy, and waxy soft wheat. Cereal Chemistry $83,551-557$

Gianibelli, M.C., Sissons, M.J., Batey, I.L., 2005. Effect of source and proportion of waxy starches on pasta cooking quality. Cereal Chemistry 82, 321-327.

Grant, L.A., Vignaux, N., Doehlert, D.C., McMullen, M.S., Elias, E.M., Kianian, S., 2001 Starch characteristics of waxy and nonwaxy tetraploid (Triticum turgidum L. var. durum) wheats. Cereal Chemistry 78, 590-595.

Grant, L.A., Doehlert, D.C., McMullen, M.S., Vignaux, N., 2004. Spaghetti cooking quality of waxy and non-waxy durum wheats and blends. Journal of the Science of Food and Agricultural 84, 190-196.

Graybosch, R.A., 1998. Waxy wheats: origins, properties, and prospects. Trends in Food Science and Technology 9, 135-142.

Guo, G., Jackson, D., Graybosch, R., Parkhurst, A., 2002. Wheat tortilla quality: impact of amylose content adjustments using waxy wheat flour. Cerea Chemistry 80, 427-436.

Kim, W., Johnson, J., Graybosch, R.A., Gaines, C.S., 2003. Physicochemical properties and end-use quality of wheat starch as a function of waxy protein alleles. Journal of Cereal Science 37, 195-204.

Mclellan, M.R., Lind, L.R., Kime, R.W., 2007. Hue angle determinations and statistical analysis for multi-quadrant Hunter L, a, b data. Journal of Food Quality 18, $235-240$.

Miura, H., Sugawara, A., 1996. Dosage effects of the three $W x$ genes on amylose synthesis in wheat endosperm. Theoretical and Applied Genetics 93, 1066-1070.

Miura, H., Araki, E., Tarui, S., 1999. Amylose synthesis capacity of the three $W x$ genes of wheat cv. Chinese Spring. Euphytica 108, 91-95.

Nakamura, T., Yamamori, M., Hirano, H., Hidaka, S., 1993. Identification of three $W x$ proteins in wheat (Triticum aestivum L.). Biochemical Genetics 31, 75-86.

Park, S.-H., Wilson, J.D., Seabourn, B.W., 2009. Starch granule size distribution of hard red winter and hard red spring wheat: its effects on mixing and breadmaking quality. Journal of Cereal Science 49, 98-105.

Pedersen, J.F., Graybosch, R.A., Funnell, D.L., 2007. Occurrence of the waxy alleles $w x a$ and $w x b$ in waxy sorghum plant introductions and their effect on starch thermal properties. Crop Science 47, 1927-1933.

Ratnayake, W.S., Jackson, D.S., 2006. Gelatinization and solubility of corn starch during heating in excess water: new insights. Journal of Agricultural and Food Chemistry 54, 3712-3716.

Schenz, T.W., 2003. Thermal analysis. In: Nielsen, S.S. (Ed.), Food Analysis, third ed. Kluwer Academic/Plenum Publishers, New York, New York, USA, pp. 517-528.

Sharma, R., Sisson, M.J., Rathjen, A.J., Jenner, C.F., 2002. The null-4A allele at the waxy locus in durum wheat affects pasta cooking quality. Journal of Cereal Science 35, 287-297.

Stone, B., Morell, M.K., 2009. Carbohydrates. In: Khan, K., Shewry, P.R. (Eds.), Wheat: Chemistry and Technology, fourth ed. AACC International, Inc., St. Paul, Minnesota, USA, pp. 299-362.

Urbano, M., Margiotta, B., Colaprico, G., Lafiandra, D., 2002. Waxy proteins in diploid, tetraploid and hexaploid wheats. Plant Breeding 121, 465-469.

Vignaux, N., Doehlert, D.C., Hegstad, J., Elias, E.M., McMullen, M.S., Grant, L.A., Kianian, S.F., 2004. Grain quality characteristics and milling performance of full and partial waxy durum lines. Cereal Chemistry 81, 377-383.

Vignaux, N., Doehlert, D.C., Elias, E.M., McMullen, M.S., Grant, L., Kianian, S.F., 2005. Quality of spaghetti made from full and partial waxy durum wheat. Cereal Chemistry 82, 93-100. 
Wehling, R.L., Jackson, D.S., Hooper, D.G., Ghaedian, A.R., 1993. Prediction of wetmilling starch yield from corn by near-infrared spectroscopy. Cereal Chemistry $70,720-723$

Yamamori, M., Nakamura, T., Nagamine, T., 1995. Polymorphism of two waxy proteins in the emmer group of tetraploid wheat, $T$. dicoccoides, T. dicoccum, and T. durum. Plant Breeding 114, 215-218.
Yamamori, M., Quynh, N.T., 2000. Differential effects of $W x-A 1,-B 1$ and -D1 protein deficiencies on apparent amylose content and starch pasting properties in common wheat. Theoretical and Applied Genetics 100, 32-38.

Zhu, T., Jackson, D.S., Wehling, R.L., Geera, B., 2007. Comparison of amylose determination methods and the development of a dual wavelength iodine binding technique. Cereal Chemistry 85, 51-58. 